\title{
THE DEVELOPMENT OF AN IMPROVED LABOUR PLANNING SYSTEM FOR MINES
}

\author{
L.D. Meyer ${ }^{1}$, D L W Krueger ${ }^{2}$, and E H Mathews ${ }^{3}$ \\ $1,2,3$ Faculty of Engineering \\ North West University, South Africa \\ ${ }^{3}$ Consultant to TEMM International \\ 1‥meyer@mweb.co.za, ${ }^{2}$ kruegerd@mweb.co.za, \\ 3ehmathews@researchtoolbox.com
}

\begin{abstract}
The mining industry is the largest source of foreign income for South Africa. It is also the main source of employment in the country. The focus of this study was to investigate the current underground labour planning models used in the platinum mines and to design an improved planning model for the optimal utilisation of labour. Financial modelling showed that an additional R38 million was realised for a platinum mine by increasing revenue on the mining side and at the same time decreasing labour costs.
\end{abstract}

\section{OPSOMMING}

Die mynbounywerheid is Suid-Afrika se grootste bron van buitelandse valuta asook die hoofbron van sy werkverskaffing. Die doel van hierdie studie was om die huidige produksie- en arbeidsbeplanning, en arbeidsbestuur vir ondergrondse mynbousisteme, soos tans in gebruik in die platinum mynbou-nywerheid, te ondersoek en te optimeer. Na suksesvolle implementering van hierdie projek is 'n finansiële analise gedoen en is bevind dat die inkomste vir 'n bepaalde platinummyn met R38 miljoen per jaar verbeter het. 


\section{INTRODUCTION}

This paper describes a new labour planning system as implemented on one of South Africa's platinum mines. By means of a relatively simple revision in the approach, significant benefits have been realised.

It must be emphasised from the start that the described approach does not replace existing software planning packages, but merely shows another way of implementing and using them.

Several new software packages were released during the past thirty years or so and some of these, like Data mine [1] and Cads mine [2], are widely used. These are however specialist packages and are not totally user-friendly to the untrained. They are also not simple for optimisation and scenario planning in the way that managers require for quick decision-making.

The constant drive for productivity improvement results in less people producing at higher levels from the same environments as in the past. This reduces the exposure risk, but since shortcuts are often taken, it also can result in unsafe work.

For the purpose of this exercise, the emphasis will be on the interrelationship between the main activities and some aspects surrounding it, i.e. the services, equipment, and infrastructure inputs supporting the main activities to arrive at the optimum output levels.

Figure 1 describes the half-level suite of a typical breast-mining layout. Note that each level is divided into two half levels by the "shaft" (east and west). Each half level contains all the mining activities mentioned before (development, ledging, equipping, stoping, vamping and reclamation) and is independent from any other half level. It is thus the smallest self-sufficient unit encompassing all mining activities.

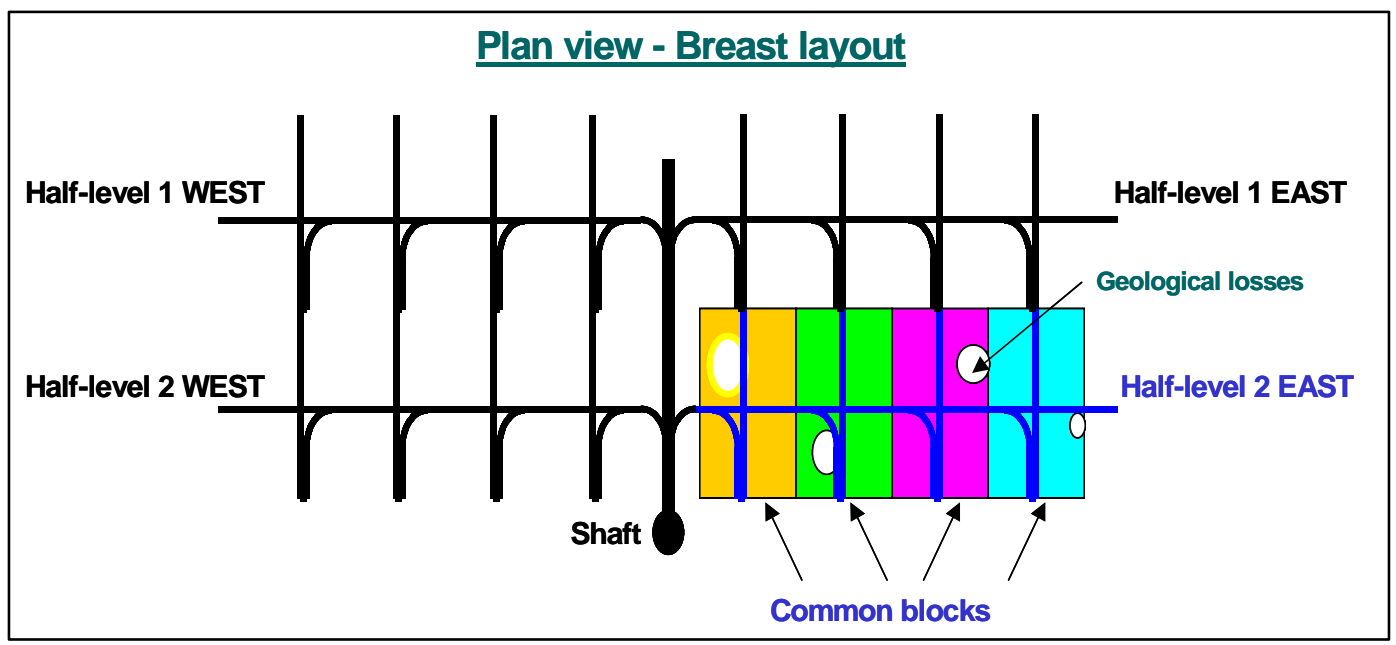

Figure 1: Plan view of the half-level suite 


\section{BACKGROUND TO THIS STUDY}

\subsection{Conventional Mine Production Planning}

Conventional mine production planning is done based on the past experience of the production personnel. Historical output levels are used as a basis for future plans and mining layout changes are made at the discretion of management $[1,2,3,4,5]$.

It is thus inevitable that building on previous inefficiencies often occurs, resulting in crisis management conditions. Where the management turnover is high, one often finds that layouts change constantly, depending on the preferences of the different managers, thus causing mines never to reach steady state (layout-optimum) production levels.

This is extremely costly and inefficient, as most layouts can take more than two years to reach full production. Ore reserve management becomes virtually impossible and flexibility suffers constantly. If better systems were in place, this would reduce the negative impact on the ore reserves.

Some mines make use of manually calculated parameters that form part of their mine standards and procedures documents, (Vermeulen [6]), but this seldom caters for all possible layouts and conditions.

\subsection{Highest Costs: Labour}

Labour cost is the highest single cost item on a mine. The labour cost in South African mines can be up to $50 \%$ of total on-mine costs, Vermeulen [7].

In the mines, a daily cycle, Troll [8], has to be completed to achieve the targets. This cycle consists of the following activities: cleaning, drilling of blast holes, chargingup of explosives and the installation of support. A specific number of employees are assigned to this cycle. Each employee is trained to do a specific task in this mining cycle.

When any employee is not on the job to perform a task in the cycle, the cycle cannot be completed. It can only be done if that specific employee is back on the job. Another employee of the same job category can also complete that specific task. Every time a cycle is not completed, there is a loss in revenue, but the total cost has already been incurred.

Only the correct number of labourers on the stope panel will ensure a quality blast. The revenue will also increase due to more panels being blasted. If there is a shortage of labourers, the mine cannot achieve a daily blast.

In any operation there is a difference between what production should be possible to achieve with specific ore reserves and mine planning, and what has actually and practically been achieved. In the group this difference is defined as the GAP. 
Lost blasts are the primary reason for a loss in revenue, and for an increase in the GAP.

\subsection{Motivation for this study}

A study was launched to investigate the current labour planning practices on a specific SA platinum mine. Results clearly indicated that there was a need for an improved labour planning system.

The primary problem with the current system was that because the monthly targets were determined by one-twelfth of the annual target, the daily targets differed from month to month.

This resulted in the following problems:

- Daily targets differ every month.

- The labour numbers vary because the labour numbers are calculated on the monthly targets.

- Due to this varying labour number in certain months, there is an oversupply or undersupply of labour.

- The inconsistent labour requirement results in a low morale among workers.

- This syndrome also expresses itself in a high rate of absenteeism and the abuse of sick leave.

\section{DESCRIPTION OF CURRENT PRACTICES}

\subsection{Problems identified in the Study}

The following observations were made during the study:

- There is a lack of standards in the up-front plan; this results in differing planned monthly production outputs.

- This in turn results in excess staff and forced leave, which results in staff changes, absenteeism and leave variations.

- The final impact is in the bottom line through less than optimum labour utilisation and unnecessarily high labour costs.

The yearly production targets are divided by the number of months in the year, which results in equal monthly targets. There are, however, different numbers of blasting shifts in each month.

The monthly targets are divided into the blasting shifts for the specific month to give a daily target. Since there are different shifts in the months, the daily target differs every month. The daily targets can therefore be either higher or lower than average.

To determine the labour requirement for the mine, factors based on production planning are used to determine the labour numbers. Because the monthly targets differ, the labour numbers also differ. The change in numbers makes it impossible to 
manage the employees optimally. In Figure 2 the labour process cycle shows the consequences of the change in production targets; sometimes there is excess of staff and during some months a shortage of staff.

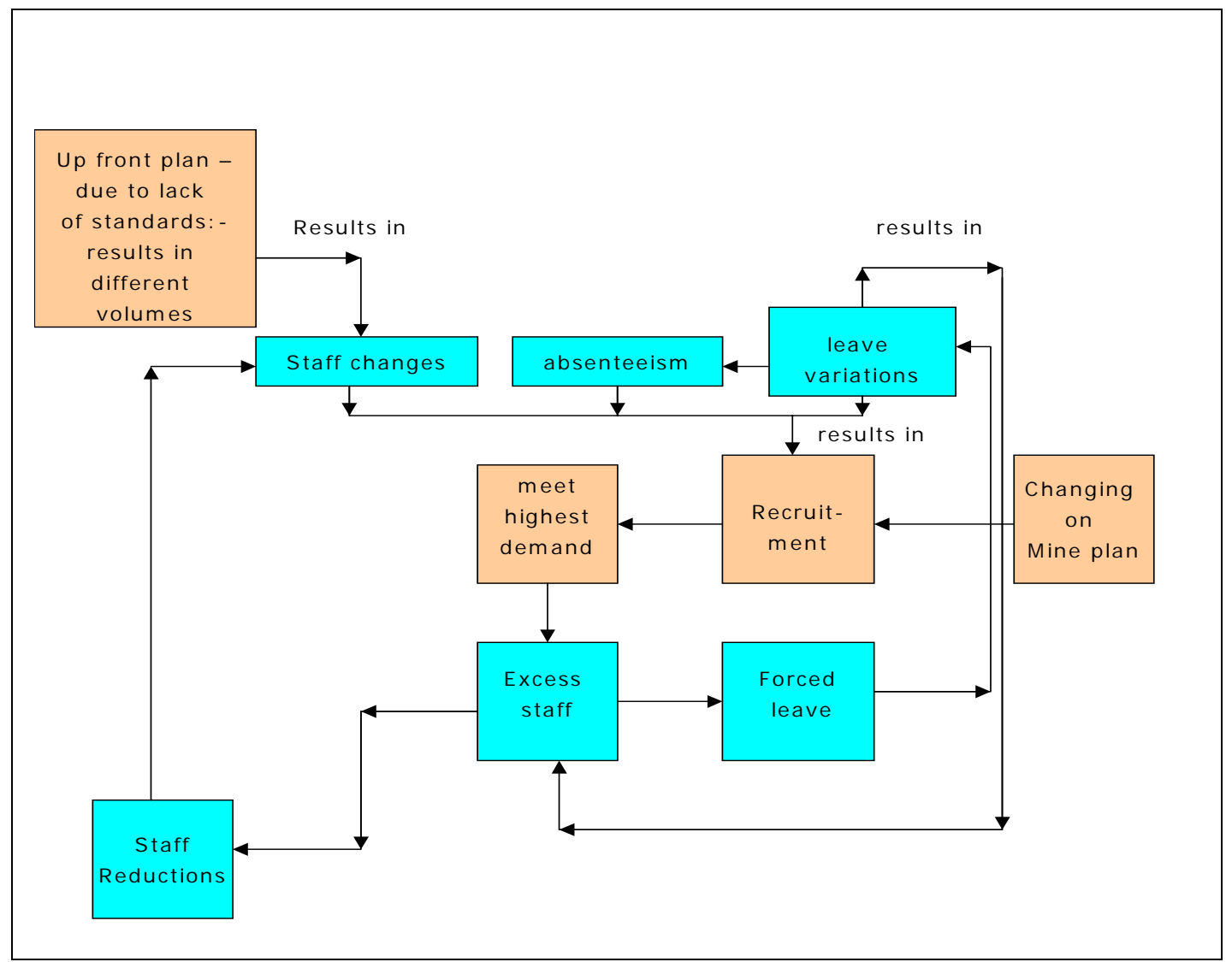

Figure 2: The problems and causes of the current process

When there is an excess of staff, the employees are forced to go on unplanned leave. When there is a shortage, however, the production targets are not met and the employees are not allowed to take annual leave. Six weeks are required to recruit and train employees, but when they are ready to commence work, the targets have frequently changed and there may once more be a surplus.

The current practice results in a low level of morale due to human resource problems. Since there is no proper labour planning system in operation, it follows that an inconsistent number of employees is supplied to the operations. This results in either a shortage of employees and at other times in an oversupply.

When there is a shortage of employees, few or none of the production targets are met, and when this happens, the employees do not get bonuses.

When there are too many employees on the job, they informally arrange to take turns to be absent and to share the bonus in the event of reaching the target. However, bonuses are often lost due to low efficiency [9]. 
This situation demoralises the employees. An attitude of carelessness is common since they feel that the supervisors do not care about their well-being. That is why the syndrome also expresses itself in a high rate of absenteeism and the abuse of sick leave.

\subsection{Blasting Efficiency}

Blast efficiency refers to the blast frequency (actual blasts/possible blasts) multiplied by the advance efficiency (actual advance per blast/maximum possible advance per blast), Troll [8]. The old planning system did not take the blasting efficiencies in the development ends and stoping panels into consideration. Consequently the production plan was overstated and impossible to achieve.

\subsection{Production Planning}

The current production planning method is not formalised - each mine uses different methods and parameters. Even here, there are only planning parameters for stoping and development - not for other work required (mining services) such as engineering, human resources, shafts and general support departments.

Production planning volumes form the basis of any labour planning system. Production targets are determined annually during budget planning, which takes place four months before the new financial year.

For budgeting, the annual figure is divided into 12 intervals. The monthly figures become the monthly production targets. Because months consist of a different number of production shifts, it follows that the daily production targets differ from month to month.

Production planning is done according to a mine master plan. The previous year's results are not taken into consideration, because lost blasts and poor advance per blast, which are expressed as blast efficiency, are not used when the planning is done. This plan is done in the knowledge that the targets cannot be met.

This is a major reason why the GAP is so big; the blast efficiency was $74 \%$ for stopping and $86 \%$ for development at the shaft where the study had been done. This means that only $74 \%$ of the production plan was actually achieved, but the planned total cost had been incurred.

\subsection{Annual Leave}

As a general rule, leave planning is not done on the mines. Employees are normally told one day before their leave commences that they have to go on leave, without any prior arrangements. The employee then still has to wait for up to three days before receiving his leave pay.

On returning from leave he has to wait for a vacancy in his job category before he can be signed back on the mine. This takes between three and fourteen days. 
The ex-leave employee goes to the training centre between four and fourteen days before commencing work. During this period there is a labour shortage in the operations and the employees in the operations cannot overhaul lost production.

As a result of the different amount of labour required on a monthly basis, there is no leave planning. Employees are sent on leave according to a weekly actual-labour figure. This means that the workers are forced to take leave at a day's notice. The employees are penalised if leave is taken before the leave cycle is completed and only receive a pro-rata leave bonus.

\subsection{Absenteeism}

Absenteeism refers to the time that an employee is not on the job during scheduled working hours, except for granted leave of absence or holiday time, Bobbin [10,11]. Absenteeism on the mine being studied was significantly in excess of what was planned.

\section{DEVELOPMENT OF THE IMPROVED LABOUR PLANNING MODEL}

\subsection{Background}

It was shown in paragraph 3.3 that the blasting efficiency for stoping is $74 \%$ and $86 \%$ for development. These results have now been brought into consideration in the labour planning model.

By setting the targets at $100 / 74=135 \%$ rather than $100 \%$, it can be predicted with relative certainty that $100 \%$ of the stoping target can be reached. Similarly, the development target in the new plan at $116 \%$ of the production should be achieved.

In addition, the ratio of production to non-production employees of 40:60 has been changed to 50:50. This means that to achieve the additional production, the total number of employees will increase slightly. Some of the non-production employees will be trained and transferred to production.

It was found that the relative reduction of non-production employees did not detrimentally influence the services department.

The GAP in the old system was $26 \%(100-74)$ for stoping. By increasing the target to $135 \%$ to achieve the actual target of $100 \%$, it appears that the GAP has increased to $35 \%$. This, however, was done in order to achieve the required production targets.

The GAP of 35\% can now be addressed by management and reduced through better utilisation in accordance with the new labour system.

\subsection{Description}

The fundamental difference between the old and the new approach is that, instead of dividing the annual production target by 12 to obtain the monthly production targets 
(from which the daily targets are then derived), the annual target is divided by the total number of shifts in the year to obtain these daily targets.

This gives a constant production target per shift and a constant labour force. Stope panels to be blasted and development ends to be blasted will be calculated. A team of employees will be allocated to each panel and each type of development end. This method will ensure a constant labour plan and this will assist in labour control and leave management.

\subsection{Labour Planning (LP)}

The improved LP system determines the exact number of employees that are required on a daily basis on a full production shift. By using this system, the labour figure for the entire mine is obtained on a daily basis.

When employees return from leave, they have to spend 4 to 12 days in the training centre. The LP system includes this requirement to ensure that there is no labour shortage on the working faces. The additional planned employees will be the equivalent of employees going on leave on a weekly basis.

Whereas the LP system is now based on a constant production target for the year, labour requirements do not vary from month to month as in the past. When production targets change during the year, the Human Resource Department is informed three months in advance so that the necessary arrangements can be made.

\subsection{Summary}

The LP system is user-friendly and focuses management's attention towards optimising from the smallest independent production unit, namely the half level. Attention is directed towards individual development ends, instead of on the total mine planned development rate, thus eliminating more difficult development ends from being neglected.

The focus is also directed towards revenue awareness. Layouts can be optimised on a technical as well as financial basis without expert assistance.

\section{DETAILED LP SYSTEM IMPLEMENTATION}

\subsection{Introduction}

The improved LP system uses production parameters, which were established during the study, to formalise the labour planning for underground mines. These production parameters may differ from mine to mine and the plan can be changed to cater for the differences.

The model has the flexibility to incorporate mine-specific requirements and is constantly developed further with mine involvement. It also has the potential for further development into an operating cost/profitability planning model that will 
make it a total business profitability-planning tool.

\subsection{Production Requirements}

The following parameters per half level were established during the investigation and are now used as standard in the LP model:

- Ore tons - The amount of broken tons per day is required as input into the Labour Planning Model.

- Working shifts - The total number of blasting shifts for the calendar year is determined by adding all the monthly blasting shifts.

- Development - Calculating the total development metre to be blasted.

- Stoping - The total number of square metres required for the year is used to calculate the daily square metre target; this is obtained by dividing the total number of square metres by the total number of shifts for the year.

- Logistics - The average tramming distance in kilometres is the distance between the tipping point and the furthest draw point.

- Stoping general - The stope general employees are the additional workers that carry out the services for the stoping operations.

- Shaft logistics - The shaft logistics are the activities carried out in and around a mine shaft.

- Services - are classified as the employees who are doing the maintenance, administration and managing of the labour force.

- Skilled labour - trained employees who perform supervisory duties.

\subsection{Labour}

The labour is built up by adding the development labour, stoping labour, logistics, general, shafts, services and skilled labour.

The total labour required to operate a shaft is summarised in Table 1. The constant labour requirement for the year is the ideal situation and creates no confusion between all the role players.

It can be seen in Table 1 that the total number of employees of 786 "in service" is constant for the year on a daily basis.

\subsection{Leave Planning}

Leave planning is now done on an annual basis. The team of employees in a work team will be consulted when leave planning is done. The supervisors know when each of the employees is due to go on leave. The allowance to carry the additional $12,5 \%$ of employees ("in service”) gives a specific number of employees. Employees are sent on leave on a weekly basis to ensure no overcrowding in the hospital during their exit interviews or take-on medical examinations, and at the training centre. The number of employees to go on leave is determined by dividing the additional employees by the number of weeks in a month. When this cycle is in operation, a natural flow of employees will occur and the number of employees going on leave, in 
the training centre and coming back from leave will be equal. All the employees are scheduled for leave to proceed on leave on the same day and return on the same day.

\begin{tabular}{|l|r|r|}
\hline & Jan-06 & Feb-06 \\
\hline UMO & 89 & 89 \\
\hline MDP (stoping) & 251 & 251 \\
\hline MDP (stoping commons) & 129 & 129 \\
\hline MO general gang & 5 & 5 \\
\hline Vamping gang & 5 & 5 \\
\hline Stope construction & 5 & 5 \\
\hline Total mining commons & 143 & 143 \\
\hline MDP (WC development) & 61 & 61 \\
\hline MDP (WC dev commons) & 10 & 10 \\
\hline MDP (shafts) & 63 & 63 \\
\hline ARM and HR & 26 & 26 \\
\hline Eng working costs & 26 & 26 \\
\hline Total underground employees & 670 & 670 \\
\hline Training & 13 & 13 \\
\hline Leave (underground) & 80 & 80 \\
\hline MDP (surface) strength & 20 & 20 \\
\hline MDP (surface) service & 22 & 22 \\
\hline Total employees (on strength) & 703 & 703 \\
\hline Total employees (on leave) & 83 & 83 \\
\hline Total employees (in service) & $\mathbf{7 8 6}$ & $\mathbf{7 8 6}$ \\
\hline
\end{tabular}

Table 1: Total labour

This procedure will ensure a constant labour flow, which will ensure a balance between the employees proceeding on leave and those returning from leave.

\subsection{Financial Benefits}

The cost of not completing the cycle (lost blast) for the day leads to a loss in revenue of R53 397 per panel. The total on mine costs is R38 826, which is a fixed cost on a mine; the revenue is calculated by making use of an equivalent value per $4 \mathrm{e}$ (Platinum, Paladium, Rhodium and Gold) gram delivered. To thus arrive at a value per shaft head 4e gram, the total revenue (after all concentrating and refining losses) has to be divided by the assayed shaft head grams. In the example a R100 per 4e gram was used for all revenue calculations.

The following benefits were calculated in terms of improved revenue and reduced costs:

Table 2 shows an improvement in revenue of R37.6 million for the mine. 


\begin{tabular}{|l|l|l|}
\hline NEW & Revenue & R19 171 141 \\
\hline & Cost & R11 444 000 \\
\hline & Profit & R7 731 141 \\
\hline OLD & Revenue & R14 186 644 \\
\hline & Cost & R9 900 000 \\
\hline & Profit & R4 286 644 \\
\hline DIFFERENCE (Shaft) & Revenue & R4 984 497 \\
\hline & Cost & R1 544 000 \\
\hline & Profit & R3 444 497 \\
\hline BENEFIT (Mine) & Profit & R37 576 327 \\
\hline
\end{tabular}

Table 2: Anticipated cost and revenue benefits

\section{CONCLUSION}

The improved labour and leave planning will reduce absenteeism on the mine, due to the improved morale, and the employees will know that the management team cares about them.

There will be sufficient employees for each one to do his/her daily tasks and employees will not have to stand in for their colleagues. More stoping employees are planned to ensure that the daily target is met.

This has an effect in the bottom line of the mine to the value of approximately R38 million.

\section{REFERENCES}

[1] The Data Mine. (27 November 2002). Available from http://www.the-datamine.com/.

[2] Cads Mine. (27 November 2002). Available from http://www.cadsmine.com.

[3] Rustenburg Platinum Mine. (2003). 2003 Business Plan. RPM, PO Box 65, Klipfontein. Conversations with Mine Manager Rudi Rudolph and Economic Research Manager Luke Zindi. RPM, PO Box 65, Klipfontein.

[4] Storrar, C.D. (1987). South African Mining Evaluation. Chamber of Mines. p 8 \& 9.

[5] Anglo American Platinum Limited. LE 12 2002. 55 Marshall St, Marshalltown, 2107. p 8 \& 9.

[6] Vermeulen. A. (2003). “Lay-out selection” Mining Optimisation. Internal memo. 55 Marshall St, Marshalltown, 2107.

[7] Vermeulen, A. (2003). Anglo Platinum MINECO presentation. Anglo American Platinum Corporation Limited Budget Report 2002 to 2006. Johannesburg; 55 Marshall St, Marshalltown, 2107. p 29 and p 33.

[8] Troll, P. (2001). Mining Optimisation Phase 2: Rediscovery - Blast Cycle and Functions. Marshalltown: MAC Consulting, 55 Marshall St, 2107. Summary

[9] Turffontein Shaft Planning Team and Anglo Platinum Cads Mine Designer. (June 2002 and October 2002). Personal Communication. 
[10] Bobbin, T. (August 1999). Absenteeism - Causes and Cures. Available from http://www.findarticles.com/cf_dls/m3638/12_40/59521650/print.jhtml.

[11] Absenteeism runs companies down. Available from http://btimes.co.za/99/0425/survey/survey14htm 